\title{
The Effect of Task-based Language Teaching in Learning Motivation
}

-Hui Wen Chua: Universiti Malaysia Kelantan, Malaysia.

Chia Ying Lin: Sultan Idris Education University, Malaysia.

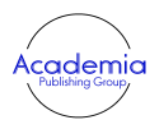

International Journal of Educational Studies

Vol. 3, No.1, pp. 16-23

2020

DOI: $10.53935 / 2641-533 x . v 3 i 1.134$

Corresponding Author: Hui Wen Chua

Funding: This study received no specific

Funding: This study received no specific

financial support.

Acknowledgements: Authors very appreciated with the management team of their center, Centre of Language Studies and Generic Development. Universiti Malaysia Kelantan by granting them the opportunity to conduct a research project entitled "Case Study „Application of Task-based Language Teaching in Teaching Mandarin as Third Language"". The research project is a research training hold by the center. This paper is part of the research project. Authors would like to thank Dr. Lin Chia Ying for her guidance along the research was carried out. Article History:

Received: 3 February 2020

Revised: 27 February 2020

Revised. 27 February 2020

Accepted. 23 March 2020

(C) 2020 by the authors; licensee Academic

(C) 2020 by the auth
Publishing Group
ABSTRACT: This study examines the effects of Task-based Language Teaching (TBLT) in 52 non-native Mandarin learners of Mandarin beginning level learning motivation and the associated factors affecting their learning motivation. Mix method design was applied in the research. Quantitative questionnaire data were analyzed using paired sample ttest to examine the differences between pre-treatment survey and first cycle post-treatment survey, and between first cycle post-treatment survey and second cycle post-treatment survey. Semi-structured interview was conducted to 11 different grade-based learners among the 52 learners in the three stages of surveys to define factors affecting learning motivation. The findings reveal that there was non-statistical decrement in learning motivation between pre-treatment survey and first cycle post-treatment survey $(t(51)=1.04, p>0.05)$, and statistical increment between first cycle posttreatment survey and second cycle post-treatment survey $(t(51)=-3.52, p<0.05)$. The findings of the interview show that learners" learning motivation is affected by the application of TBLT, busy schedule and support from Mandarin native speaker. As conclusion, the study indicates that TBLT can increase learners "learning motivation in long term application. The study also implicates that TBLT can perform well with sufficiency language input task and Mandarin native speakers" support before the output task.

Key words: Task-based language teaching, Teaching Mandarin as a foreign language, Learning motivation.

\section{Introduction}

Malaysia is aware of the importance of Mandarin as a global language when the language was firstly implemented in National Higher Action Plan 2007-2010, where tertiary students were required to learn an additional language besides the national language - Bahasa Malaysia, and second language - English. The policy is further enhanced in Malaysia Education Blueprint 2015-2025 (Higher Education) (MEB) and iCGPA Rubric Learning Outcomes Assessment Guide. Language proficiency is stressed as one of the six primary attributes found in MEB. The language proficiency attribute emphasizes on studentse proficiency in Bahasa Malaysia and English, yet the policy also emphasizes on the learning of a foreign language. According to the latest curriculum development, the integrated Cumulative Grade Point Average (iCGPA), communication is included as one of the skills students need to master. The communication skills mentioned here include conversing in different contexts by conducting effective communication using Bahasa Malaysia, English and a foreign language.

The teaching of Mandarin as a foreign language syllabus in Malaysian tertiary level is unique compared to that of China. In China, the language teaching is categorized into four language skills, such as speaking, writing, listening, and reading. While, in Malaysia, it is carried out „regardless of teaching skills ${ }^{\text {ee }}$ as written by Zhou (2009) to describe the teaching methodology that integrates all language skills without emphasizing 
on any specific language skills (cited in Hoe and Lim (2013)). Therefore, the teaching of Mandarin in Malaysia focuses more on communication and interaction.

However, throughout the implementation and enhancement of the mentioned foreign language policy, learners have voiced up their fear as they are unable to communicate effectively in the language they learned. There are many probable causes, such as the interference of their mother tongue and insufficient learning time (Cheun (2006) as cited in Tan, et al, 2016), as well as limited opportunities to use the target language on daily basis (Jeon \& Hahn, 2006). These factors have caused them to become less-likely motivated to learn the language. Moreover, from the interview between the learners and the teachers, the researcher found that the learnerse motivation tends to drop when they started their Mandarin level 2 course. Therefore, it may be helpful for non- native learners of Mandarin to be provided with authentic pragmatic usage to give them proper exposure towards language use in class.

Regarding the language practice opportunities, Tan, Ooi, and Hairul (2012) had suggested that Mandarin teachers should adopt suitable teaching approaches to take full advantage of the learning orientations. This study was supported by Tan, Lin, and Hoe (2017) which showed that the target language learning experience that contained of learning pleasure, classroom atmosphere, and teaching approach played an essential role in studentse learning achievement. Hence, Task-based Language Teaching (TBLT) seems to offer several advantages to cope with the phenomena in Mandarin practice. This is because, TBLT is an approach that provides students with opportunities to have active engagement in communication in order to achieve a goal or to complete a task. The application of TBLT is popular in the teaching of Mandarin as a second language in China context, where the application of TBLT is more focused on each language skill. There is a lack of research in the teaching of Mandarin as a foreign language in Malaysia context. Hence, this research is to investigate the influence of TBLT on non-native Mandarin learners ${ }^{\text {ee }}$ learning motivation.

The research objective is mainly to investigate the effect of TBLT in non-native Mandarin learnerse learning motivation and to find out the associated factors that influence Mandarin learning motivation during the application of the teaching approach. Thus, two research questions were created based on the research objectives:

1. Are there any effects of TBLT in non-native Mandarin learners ${ }^{e e}$ learning motivation?

2. What are the associated factors influence the learning motivation during application of TBLT?

\section{Literature Review}

\subsection{Task-based Language Teaching (TBLT)}

Task-based Language Teaching (TBLT) is an approach applied in the teaching of a second or a foreign language that was firstly implemented in his Bangalore project in India. The teaching approach engages learners to perform a series of tasks in an interactional authentic language environment (Murad, 2009) by using the target language for communication. The activities in the task should relate to daily work or in other words, the task is focused on real-life situation process-oriented teaching approach, where communicative competence is the main objective of the language teaching. However, the communicative competence mentioned is not referred to the ability to use the language correctly and appropriately as a native speaker, but it aligns with Kouckaes concept, it is about the communicative language that promotes the ability to communicate competently to accomplish a communication goal (Koucká, 2007). Yet, during the process of learning, TBLT aims not only to enable learners to acquire new linguistic knowledge, but also to enhance their existing knowledge. Hence, from this point, it could be said that TBLT involves both inputproviding and output- prompting tasks, where a simple input-based task initially is used to build up target language proficiency. Thus, features of TBLT are emphasized on meaningful learning, involvement on real world process of language use and engagement of cognitive process (Ellis, 2009).

\subsection{TBLT Learning Motivation}

The introduction of TBLT in foreign language context has given a positive impact on learning outcomes as researchers discovered that TBLT could increase learners ee learning motivation. This is because TBLT creates a positive learning environment to promote learners" enjoyment (McDonough \& Chaikitmongkol, 2007) and decreases learners"e learning anxiety by boosting their confidence (cited in Bao and Du (2015)). Besides that, Motallebzadeh and Defaei (2013) in their research also proved that TBLT listening activities promoted improvement of listening self-efficacy among EFL intermediate learners. 


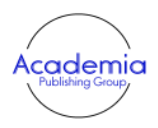

International Journal of Educational Studies

Vol. 3, No.1, pp. 16-23

2020

DOI: 10.53935/2641-533x.v3i1.134

- Corresponding Author: Hui Wen Chua Funding: This study received no specific inancial support.

Acknowledgements: Authors very appreciated with the management team of their center, Centre of Language Studies and Generic Development, Universiti Malaysia Kelantan by granting then the opportunity to conduct a research project entitled "Case Study ,Application of Task-based Language Teaching in Teaching Mandarin as Third Language"". The research project is a research training hold by the center. This paper is part of the research project. Authors would like to thank Dr. Lin Chia Ying for her guidance along the research was carried out.

Article History:

Received: 3 February 2020

Received. 3 February 2020

Revised. 27 February 2020

Accepted: 23 March 2020

(C) 2020 by the authors; licensee Academic Publishing Group
Number of researches had been done in the context of teaching Mandarin as a foreign language have also suggested similar views. For instance, found that the use of TBLT among lower-secondary learners assisted in increasing their participation and spurred their interests in the learning process. The same condition happened in Chinese characters learning among high-school learners as reported by Kirkebæk (2012). Moreover, Bao and Du (2015) also proved in their study that TBLT contributed learners in term of increasing participation, creating more opportunities for speaking, easing learners ${ }^{\text {ee }}$ anxiety, and enhancing enjoyment.

The above highlighted the case of teaching Mandarin as a foreign language in countries outside of China towards non-native speakers. For teaching of Mandarin as a second language in China context, Zhang (2016) has done her research on the application of TBLT in one international school in China and the result has shown that the teaching approach could enhance non-native Mandarin studentse enthusiasm and interest in learning Mandarin. However, the researcher points out the problem of TBLT application that although students seemed enthusiastic in completing task, but their Mandarin learning is questionable. Hence, there is a need to find out students ${ }^{\text {ee }}$ point of view about their learning motivation during the application of TBLT.

Observing the application of TBLT in teaching Mandarin as a foreign language as well as teaching English as second language (TESL) or foreign language teaching in Malaysia context, the application of TBLT is lacking. Only one research has been done by Chua (2019) about comparing the influence of TBLT and audio-lingual teaching approach in teaching Mandarin as a foreign language among non-native Mandarin beginnerse learning motivation. The research has shown that TBLT could increase studentse learning motivation for a long run by decreasing their learning anxiety, but audio-lingual teaching approach would decline learners ${ }^{c e}$ learning motivation over time.

\section{Method}

This research adopted a mix-method approach through quantitative and qualitative studies, where time series design was the main core of the research design. As suggested by Fraenkel, Wallen, and Hyun (2015), this type of research design includes typical pre- and post-treatment tests, observations or measurements taken before and after treatment. There were 52 learners participated in the quantitative study, while only 11 selected students from the 52 learners were participated in the qualitative study. The research had been carried out for eight weeks. The 11 students were selected based on their Mandarin level 1 grade as shown in Table 1 below.

Table-1. The Demographic Information of Interviewees

\begin{tabular}{lllll}
\hline No. & Students' nicknames & Gender & Race & Mandarin Level 1 Grades \\
\hline 1. & Zuraida & Female & Malay & A \\
2. & Nurhazirah & Female & Malay & A \\
3. & Janagi & Female & Indian & A- \\
4. & Farida & Female & Malay & A- \\
5. & Masturina & Female & Malay & B \\
6. & Sharida & Female & Malay & B- \\
7. & Puteri & Female & Malay & B \\
8. & Syazwani & Female & Malay & C+ \\
9. & Faizudin & Male & Malay & C+ \\
10. & Ummi & Female & Malay & C+ \\
11. & Badihah & Female & Malay & C- \\
\hline
\end{tabular}

The subjects of the research consisted of 52 non-native Mandarin learners, who were taking Mandarin level 2 in Universiti Malaysia Kelantan. The duration of the research was almost three months from 20 February 2018 until 26 April 2018. Convenience sampling was applied in the research due to the overlapping timetable between the teacher and researcher. The sample was chosen based on certain criteria, in which students must have taken their Mandarin level 1 and have passed the exam for the course as a prerequisite for Mandarin level 2 course. 
The adaptation of Willis (1996) TBL framework that includes three main phrases: pre-task, duringtask and post-task as well as the private and public use in the „during-taske phase as shown in Figure 1 below was applied in this study. In this study, there were two cycles of task applied, where the first task was about selling goods, while the second task was about face to face appointments and phone call appointments. Both tasks consisted private and public use in the „during task ${ }^{\text {ee }}$. The private use in the „during task ${ }^{\text {ee }}$ for the first task cycle involved peer learning between the learners and their partners.

While the public use in the ,during task ${ }^{e e}$ involve all learners in the class, where they are divided into groups with all the groups played a different role, where there were two groups of food seller, two groups of fashion seller and two groups of consumers. When they were doing the tasks, the teacher would record their performance that would be played after the task completion for the teacher and the learners to comment. The second task also involved private and public use, where the private use in ,during-task ${ }^{\text {ee }}$ involved a pair work conversation practice based on a situation that they had chosen. Meanwhile, during the public use of the "during task", learners need to present their conversation in front of the class, where their presentation will be commented by their classmates and the teacher.

\begin{tabular}{lll}
\hline $\begin{array}{l}\text { Pre-task } \\
\text { Setting: In the classroom }\end{array}$ & During task & Post-task \\
& $\begin{array}{l}\text { Private use: } \\
\text { Teacher conducts pre-task Practice between partners }\end{array}$ & $\begin{array}{l}\text { The recorded conversations } \\
\text { play and received comments } \\
\text { based on textbook }\end{array}$ \\
& $\begin{array}{l}\text { from their teacher and other } \\
\text { learners in their class. }\end{array}$ \\
& $\begin{array}{l}\text { Public use: } \\
\text { Having presentation of their task in } \\
\text { front of their class } \\
\text { (the conversations were recorded) }\end{array}$ \\
\hline & Figure-1. Adaptation of Willis"s TBL Framework
\end{tabular}

The quantitative study in the research adapted a questionnaire from in which the first and second part of the questionnaire was taken and adapted. The questionnaire consisted of intrinsic motivation, extrinsic motivation, task value and control of learning belief, while the second part included of ideal L2 self and ought to L2 self. Therefore, the questionnaire was about learners "e learning motivation. The questionnaire was delivered to study how learnerse perspectives changed due to the application of TBLT. Hence, the questionnaire was firstly delivered to the participants during pre-treatment survey. Next, the same questionnaire was delivered to the participants during first cycle post-treatment survey and second cycle post-treatment survey. The questionnaire used in this research was 5-point Likert scale.

A semi-structured interview was applied in the qualitative study in the research. The semi-structured interview questionnaire adapted from Campbell and Storch (2011) guiding questionnaire, which was mainly about studentse perspectives on what associated factors that attribute to their success and not success in Mandarin learning and others factors that happened outside of classroom that affected their learning motivation. The semi- structured interview was firstly carried out during pre-treatment survey to discover the students ${ }^{\text {ee }}$ learning motivation before the application of TBLT. The second and third semistructured interview took place during first cycle post-treatment survey as well as second cycle posttreatment survey to discover the associated factors caused in the changes on their learning motivation. The analyses for the quantitative data were conducted using paired sample t-test. On the other hand, semistructured interviews of 11 selected students were collected and transcribe word by word by a transcriber and translated into English. Transcripts were analyzed individually and collectively, by using a horizontal and vertical content analysis process, to confirm and refute categories and develop themes and patterns. Categories were then confirmed, refuted, or expanded in subsequent discussion between researchers. Validity was attained through triangulation of data. 
4. Results and Discussion

4.1. Research Question 1: Are There Any Effects of TBLT in Non-native Mandarin Learners' Learning Motivation?

A paired sample t-test was conducted to compare the result of learning motivation between pre-treatment survey and first cycle post-treatment survey and the results were showed in Table 2 and 3 below. There was no significant difference in the learning motivation between pre-treatment test $(\mathrm{M}=131.21, \mathrm{SD}=17.59)$ and first cycle post-treatment survey $(\mathrm{M}=127.92, \mathrm{SD}=13.43), \mathrm{t}(51)=1.04, \mathrm{p}>0.05$. Hence, the null hypothesis was accepted.

Table-2. Descriptive Analyses between Pre-treatment Survey and First Cycle Post-treatment Survey

\begin{tabular}{lll}
\hline Group & M & SD \\
\hline Pre-treatment test & 131.21 & 17.59 \\
First cycle post-treatment test & 127.92 & 13.43 \\
\hline
\end{tabular}

These results suggest that TBLT does not have any effect on learning motivation during first cycle posttreatment survey. The result showed that when TBLT was applied in Mandarin learning, the learning motivation tend to be declined during first cycle post-treatment test.

Table-3. Inferential Statistic between Pre-treatment Test and First Cycle Post-treatment Survey

\begin{tabular}{|c|c|c|c|c|c|c|c|c|}
\hline & & & \multicolumn{3}{|c|}{ Paired Differences } & \multirow[t]{2}{*}{$\mathbf{t}$} & \multirow[t]{2}{*}{ df } & Sig. \\
\hline & $\mathrm{M}$ & SD & $\begin{array}{l}\text { Std. } \\
\text { Error } \\
\text { Mean }\end{array}$ & $\begin{array}{l}95 \% \mathrm{Cl} \\
\text { Lower }\end{array}$ & Upper & & & $\begin{array}{l}(2- \\
\text { tailed) }\end{array}$ \\
\hline $\begin{array}{l}\text { Pre-treatment test } \\
\text { and first cycle } \\
\text { post-treatment test }\end{array}$ & 3.29 & 22.83 & 3.17 & -3.07 & 9.65 & 1.04 & 51 & 0.30 \\
\hline
\end{tabular}

A paired sample t-test was conducted to compare the result of learning motivation between first cycle post- treatment survey and second cycle post-treatment test and the results were showed in Table 4 and 5 below. There was significant difference in the learning motivation between first cycle post-treatment survey $(\mathrm{M}=127.92, \mathrm{SD}=13.43)$ and second cycle post-treatment survey $(\mathrm{M}=138.27, \mathrm{SD}=14.66), \mathrm{t}(51)=-3.52$, $\mathrm{p}<0.05$. Hence, the null hypothesis was rejected.

Table-4. Descriptive Analyses between First Cycle Post-treatment Test and Second Cycle Post-treatment Test

\begin{tabular}{lcc}
\hline Group & M & SD \\
\hline First cycle post-treatment test & 127.92 & 13.43 \\
Second cycle post-treatment test & 138.27 & 14.66 \\
\hline
\end{tabular}

These results suggest that TBLT has an effect in learning motivation for second cycle post-treatment survey. The results showed that when TBLT was applied in Mandarin learning, the learning motivation tend to be inclined during second cycle post-treatment test.

Table-5. Inferential Statistic between First Cycle Post-treatment Test and Second Cycle Post-treatment Test

\begin{tabular}{|c|c|c|c|c|c|c|c|c|}
\hline & & & \multicolumn{3}{|c|}{ Paired Differences } & \multirow[t]{2}{*}{$\mathbf{t}$} & \multirow[t]{2}{*}{ df } & \multirow{2}{*}{$\frac{\text { Sig. }}{\text { (2-tailed) }}$} \\
\hline & $\mathrm{M}$ & $\mathrm{SD}$ & $\begin{array}{l}\text { Std. } \\
\text { Error }\end{array}$ & $95 \% \mathrm{CI}$ & & & & \\
\hline $\begin{array}{l}\text { First cycle post- } \\
\text { treatment test and } \\
\text { second cycle post- } \\
\text { treatment test }\end{array}$ & -10.35 & 21.17 & $\begin{array}{l}\text { Mean } \\
2.94\end{array}$ & $\begin{array}{l}\text { Lower } \\
-16.24\end{array}$ & $\begin{array}{l}\text { Upper } \\
-4.45\end{array}$ & -3.52 & 51 & 0.00 \\
\hline
\end{tabular}

Acknowledgements: Authors very appreciated with the management team of their center, Centre of Language Studies and Generic Development, Universiti Malaysia Kelantan by granting them the opportunity to conduct a research project entitled "Case Study „,Application of Task-based Language Teaching in Teaching Mandarin as Third Language"". The research project is a research training hold by the center. This paper is part of the research project. Authors would like to thank Dr. Lin Chia Ying for her guidance along the research was carried out. Article History:

Received: 3 February 2020

Revised: 27 February 2020

Accepted: 23 March 2020

(C) 2020 by the authors; licensee Academic Publishing Group
} 


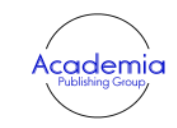

International Journal of Educational Studies

Vol. 3, No.1, pp. 16-23

2020

DOI: $10.53935 / 2641-533 x . v 3 i 1.134$

- Corresponding Author: Hui Wen Chua Funding: This study received no specific Funding: This study received no specific financial support.

Acknowledgements: Authors very appreciated with the management team of their center, Centre of Language Studies and Generic Development. Universiti Malaysia Kelantan by granting them the opportunity to conduct a research project entitled "Case Study ,Application of Task-based Language Teaching in Teaching Mandarin as Third Language"". The research project is a research training hold by the center. This pape is part of the research project. Authors would like to thank Dr. Lin Chia Ying for her guidance along the research was carried out. Article History:

Received: 3 February 2020

Received: 3 February 2020

Revised: 27 February 2020

Accepted: 23 March 2020

Published: 17 April 2020 by the authors; licensee Academic Publishing Group
The drop in the learners ${ }^{e e}$ learning motivation once TBLT was applied in first cycle post-treatment test was not significant, but this condition could be explained by the findings of McDonough and Chaikitmongkol (2007) that learners react negatively towards TBLT during the introduction of the teaching approach because it did not include explicit grammar instruction (cited in Bao and Du (2015)). Once learners adapted to TBLT, their learning motivation results during second cycle post-treatment test had shown significant inclined. Hence, there is a need of time for learners to adjusting their learning to coordinate with TBLT. This result was supported by Chua (2019) in her research that TBLT could increase learners ${ }^{\text {ee }}$ learning motivation by decreasing their learning anxiety. This is because by performing a task, learners can build up their learning motivation by decreasing their learning anxiety through communication with their peers that helps them to retain the language they learned.

\subsection{Research Question 2: What are the Associated Factors that Influence the Learning Motivation during Application of TBLT? \\ 4.2.1. Influence of Teaching Approach}

According to the interview, TBLT is one of the influences on learning motivation of non-native Mandarin learners. They responded positively toward TBLT. The learners point out that TBLT further emphasized on the process of learning. Hence, they believed that the teaching approach improved their confidence in speaking Mandarin and the communication activities became more realistic. For example:

The activity that covers the tasks in buying and selling has changed me. It allows me to speak Mandarin confidently. During the general practice, we do not have person to play the role of customer, but during task performing, there are customers, they will ask questions, therefore, we need to prepare ourselves to respond toward the spontaneous questions. (Faizudin) (Interview 2) Besides that, learners also see their progression during the application of TBLT. For example, "From the very beginning, I don ${ }^{e t}$ know anything about Mandarin, but now there has a bit change in me. This is because I can hardly remember the vocabularies I have learnt in the early semester but after the application TBLT it helps in my Mandarin learning. (Sharida) (Interview 2)

Moreover, after the application on TBLT, non-native Mandarin learners addressed the improvement in their Mandarin learning when teacher applied TBLT. This is because it made them to communicate more. For example, "from the previous course, we seldom have grouping activities as we just do on our own, but from what our teacher do this semester, which was more toward interaction. The TBLT activities were fun because we can move from station to station and from there we learn to communicate" (Masturina) (Interview 2).

In addition, TBLT also encourage competition between peers. For example, "I feel like challenged as my peers, Farida and Sufian could speak fluently but I cannot speak fluently, so it encouraged me to practice Mandarin to be like them" (Putri) (Interview 2). Another example mentioned by Sharida in her second interview, "I saw that my classmates can speak Mandarin fluently in the class, which affected me at that moment" (Farida) (Interview 2).

On the other hand, one student complaint about TBLT application, where the task-based activities cause the class to be messy as every participant start their conversation: "Hence, when there have more than two persons having conversation at the same time, it is noisy, and I hardly could listen to what my peers talking about" (Nurhazirah) (Interview 2). At the same time, she also emphasized that the peers in the class which were less active or lively compared to last semester that caused the task activity to become less lively.

\subsubsection{Busy Schedule}

TBLT required learnerse ${ }^{e e}$ sufficiency language input so that they could perform well in the interactive tasks. Hence, Mandarin vocabulary learning difficulties required enough time to practice. Therefore, certain students complain about their busy schedule of their major courses that make them hardly have time to revise. For example, "I need to manage my time for studio as we have many studio projects, and we still need to prepare our Mandarin task" (Nurhazirah) (Interview 2). Nurhazirah also gives her point of view on TBLT where the Mandarin level 2 syllabus has too much vocabulary that need to be mastered in order to perform in a task that made her become less motivated. At the same time, the vocabulary has almost the same pronunciation, but different meaning, which confused me. 
Due to pack schedule that lead toward time mismanagement that make them hardly prepared themselves language input to be used in the task performance. For example, "I think it is hard for me to focus on Mandarin as I have too many programs, which is very pack, I hardly have time to open Mandarin textbook because of too many programs that I could not. A lot of programs. During mid-semester break, we have program for the whole week without resting. Although time constraint is less compared to last semester as I have plenty of time, but I do not use it wisely" (Masturina) (Interview 2).

\subsubsection{Mandarin Native Speakers Support}

Hence, the result concludes that learnerse learning motivation can be influenced by application of TBLT, but this condition is temporary for learners to adapt to the teaching approach, their learning motivation will increase once they have adapted to TBLT. The study also implicates that to enable TBLT to perform well, teacher should provide sufficient language input task for students before the output task so that it can improve learners ${ }^{\text {ee }}$ learning motivation.

\section{Conclusion}

As conclusion, the findings of this study show that TBLT can increase non-native Mandarin learners ${ }^{\text {ee }}$ learning motivation for long term application. However, the learners ${ }^{\text {ee }}$ learning motivation is decreased at the first place when TBLT is applied in their Mandarin learning. This condition is explained by the findings of McDonough and Chaikitmongkol (2007) that learners react negatively towards TBLT during the introduction of the teaching approach among university students (cited in Bao and Du (2015)). This condition could be explained by Bunmak (2017) that application of TBLT on learners of low Mandarin proficiency level or learners with zero basic target language could made them became lack of confident. This condition will change when learners have adapted to TBLT that cause their learning motivation to be significantly increased during second cycle post-treatment test.

Hence, the result concludes that learnerse learning motivation can be influenced by application of TBLT, but this condition is temporary for learners to adapt to the teaching approach, their learning motivation will increase once they have adapted to TBLT. The study also implicates that to enable TBLT to perform well, teacher should provide sufficient language input task for students before the output task so that it can improve learnerse learning motivation.

By having students who are proficient in Mandarin, such as Mandarin native speakers as learnerse Mandarin learning peers is encouraged to help in boosting their Mandarin learning motivation and that will improve their Mandarin vocabulary input. Besides that, teacher should consider the effect of TBLT in teaching Mandarin although they could not observe improvement in learners ${ }^{\text {ee }}$ learning motivation once TBLT is applied toward the learners. The effect of TBLT on learnerse learning motivation will increase once learners have adapted to TBLT.

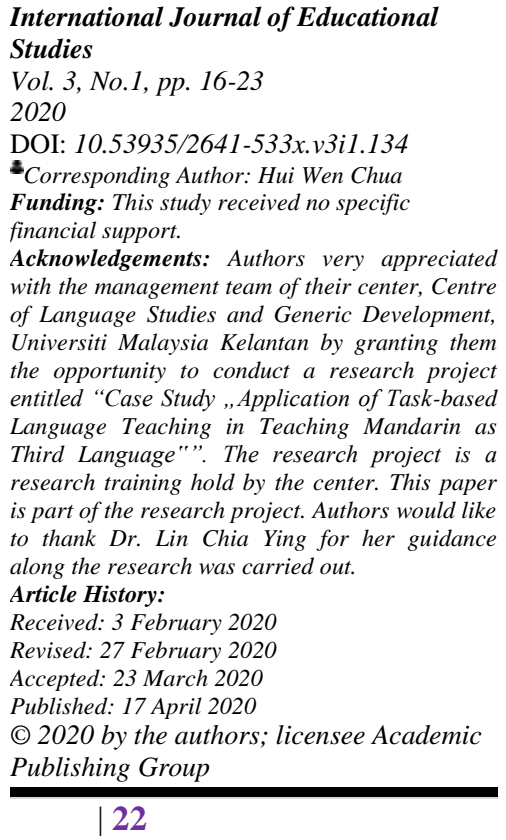

\section{References}

Bao, R., \& Du, X. (2015). Implementation of task-based language teaching in Chinese as a foreign language: Benefits and challenges. Language, Culture and Curriculum, 28(3), 291-310.

Bunmak, N. (2017). The influence of task-based learning on ELT in ASEAN context. Language Education and Acquisition Research Network, 10(1), 201-209.

Campbell, E., \& Storch, N. (2011). The changing face of motivation a study of second language learners "e motivation over time Australian Review of Applied Linguistics, 34(2), 166-192.

Cheun, H. H. (2006). Problems encountered in teaching Chinese as a second language in Malaysia. Malaysia: New Era College.

Chua, H. W. (2019). The effects of task-based language teaching and audio-lingual teaching approach in mandarin learning. Unpublished Master Thesis, Faculty of Language and Communication, Sultan Idris Education University.

Ellis, R. (2009). Task-based language learning and teaching. New York: Oxford University Press.

Fraenkel, J. R., Wallen, N. E., \& Hyun, H. H. (2015). How to design and evaluate research in education (9th ed.). New York: Mc Graw HIll.

Hoe, F. T., \& Lim, T. H. (2013). Chinese / mandarin as a second language course: A comparison between a Malaysian and Chinese and Beijing Language and Culture University As an ..., (July). Retrieved from: https://www.researchgate.net/publication/237091805_CHINESE_MANDARIN_AS_A_SECOND_LANGUAGE_COURSE A_COMPARISON_BETWEEN_A_MALAYSIAN_AND_CHINESE_UNIVERSITY_UNIVERSITI_TEKNOLOGI_MA RA AND BEIJING LANGUAGE AND CULTURE UNIVERSITY AS AN EXAMPLE.

Jeon, I., \& Hahn, J. (2006). Exploring EFL teacherse perceptions of task-based language teaching: A case study of Korean secondary school classroom practice. Asian EFL Journal, 8(1), 123-143. 
Kirkebæk, M. J. (2012). Use of tasks in teaching of Chinese characters. In X. Y. Du \&M. J. Kirkebæk (Eds.), Exploring task-based PBL in Chinese teaching and learning (pp. 111-131). Newcastle: Cambridge Scholars Press.

Koucká, A. (2007). The role of mother tongue in English language teaching PhD Theiss. University of Pardubice.

McDonough, K., \& Chaikitmongkol, W. P. (2007). Teachers" and learners"e reactions to a task-based EFL course in Thailand. TESOL Quarterly, 4l(1), 107-132.

Motallebzadeh, K., \& Defaei, S. (2013). The effect of task-based listening activities on improvement of listening self-efficacy among Iranian intermediate EFL learners. International Journal of Linguistics, 5(2), 24-33.

Murad, T. M. (2009). The effect of task-based language teaching on developing speaking skills among the palestinian secondary efl students in israel and their attitudes towards english supervisor major: Curricula and methods of teaching english as a foreign language department. Asian EFL Journal.Com.

Tan, T. G., Lin, T. H., \& Hoe, F. T. (2017). Analysing the relationship between L2 motivational self System and achievement in mandarin. International Academic Research Journal of Social Science, 3(1), 104- 108.

Tan, T. G., Ooi, A. K., \& Hairul, N. I. (2012). The orientation for learning mandarin amongst malay undergraduate students. International Journal of Humanities and Social Science, 2(12), 104-112.

Willis, J. (1996). A framework for task-based learning. UK: Longman: Harlow.

Zhang, L. (2016). The effect of task-based language teaching activities for students' learning motivation and learning effect in AP Chinese Course. Unpublished Master Dissertation. Shanghai Normal University.

Zhou, X. B. (2009). Duìwài hànyŭ jiàoxué dăolùn: The Commercial Press.

\begin{abstract}
International Journal of Educational Studies

Vol. 3, No.1, pp. 16-23

2020

DOI: $10.53935 / 2641-533 x . v 3 i 1.134$

* Corresponding Author: Hui Wen Chu

Funding: This study received no specific

financial support.

Acknowledgements: Authors very appreciated with the management team of their center, Centre of Language Studies and Generic Development, Universiti Malaysia Kelantan by granting them the opportunity to conduct a research project entitled "Case Study ,Application of Task-based Language Teaching in Teaching Mandarin as Third Language"”. The research project is a research training hold by the center. This paper is part of the research project. Authors would like to thank Dr. Lin Chia Ying for her guidance along the research was carried out. Article History:

Received: 3 February 2020

Received: 3 February 2020

Revised: 27 February 2020

Accepted: 23 March 2020

(C) 2020 by the authors; licensee Academic

Publishing Group
\end{abstract}

